\title{
Standar Pendidik dan Tenaga Kependidikan
}

\author{
Rezi Yuhanda Nasdi \\ Universitas Negeri Padang \\ Indonesia \\ E-mail : reziyuhandanasdirezi674@gmail.com
}

\author{
Hade Afriansyah \\ Universitas Negeri Padang \\ Indonesia \\ E-mail : hadeafriansyah@fip.unp.ac.id
}

\begin{abstract}
Abstrak - Educators are individuals who are able to carry out educational actions in one educational situation to achieve educational goals. The teaching staff is such as teachers, lecturers, counselors, tutors, widyaiswara, tutors, instructors and facilitators. Every educator has their respective positions, having a role in accordance with their position and function. Each other complements, no one occupies a dominant position in contributing to efforts to achieve educational goals. The role or task of the teacher is as an educator, teacher, mentor, director, coach, appraiser and evaluator of the students. The role is carried out in order to achieve educational goals. As educators, they must have a strategy or way for their students to succeed in education.
\end{abstract}

Keywords - Educators; Education

\section{Pendahuluan}

Pendidikan merupakan usaha manusia untuk menumbuhkan dan mengembangkan potensi-potensi pembawaan baik jasmani maupun rohani sesuai dengan nilainilai yang ada dalam masyarakat dan kebudayaan (Ikhsan, 2003:2). Sehingga kemajuan suatu bangsa tidak terlepas dari faktor pendidik, karena pendidikan mempunyai peranan penting dalam usaha meningkatkan sumber daya manusia (SDM) yang merupakan unsur penting dalam pembangunan suatu bangsa. Berdasarkan UU RI No.20 Tahun 2003 Bab 1 Pasal 1 Ayat 1 tentang sistem Pendidikan Nasional mendefinisikan bahwa pendidikan adalah usaha sadar dan terencana untuk mewujudkan suasana belajar dan proses pembelajaran agar siswa secara aktif mengembangkan potensi dirinya untuk memiliki kekuatan spiritual keagamaan, pengendalian diri, kepribadian, kecerdasan, akhlak mulia serta keterampilan yang diperlukan dirinya, masyarakat, bangsa dan Negara.

Pendidik merupakan orang yang memiliki peran penting dalam kehidupan. Disebabkan karena ia memiliki tanggung jawab untuk menentukan arah pendidikan. Itulah sebabnya Islam sangat menghargai dan menghormati orang-orang yang berilmu pengetahuan dan bertugas sebagai pendidik. Islam mengangkat derajat mereka dan memuliakan mereka melebihi dari orang Islam lainnya.

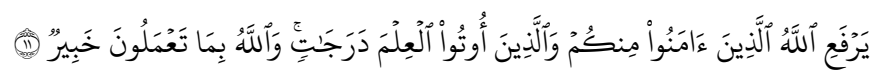

Allah akan meninggikan orang-orang yang beriman di antaramu dan orang-orang yang diberi ilmu pengetahuan beberapa derajat. dan Allah Maha mengetahui apa yang kamu kerjakan.(QS. Al-Mujadalah/58: 11).

\section{METODE PENELITIAN}

Artikel ilmiah hendaknya disusun dengan metode dan langkah-langkah yang sistematis untuk memudahkan dalam melakukan penelitian. Pada artikel ini, peneliti menggunakan metode dengan terlebih dahulu mengumpulkan bahan kajian dan materi dari sumber buku, jurnal, artikel, maupun sumber lainnya yang berkaitan dengan ilmu dari Administrasi Pendidikan. Menurut Sugiyono (2009) penelitian kualitatif adalah suatu metode penelitian yang berlandaskan pada filsafat postpositivisme, digunakan untuk meneliti pada kondisi objek yang alamiah dimana peneliti adalah sebagai instrumen kunci, pengambilan sampel sumber data dilakukan secara purposive, teknik pengumpulan dengan triangulasi, analisis data bersifat induktif/kualitatif, dan hasil penelitian kualitatif lebih menekankan makna dari pada generalisasi. Metode kualitatif dimaksudkan untuk memahami fenomena tentang apa yang dialami oleh subyek penelitian, misalnya perilaku, persepsi, tindakan, dll, secara holistik dengan cara deskripsi dalam bentuk kata-kata dan naratif pada suatu konteks khusus yang alamiah dan dengan memanfaatkan berbagai metode ilmiah.

\section{KAJIAN TEORI DAN PEMBAHASAN}

\section{A. Pengertian Pendidik}

Dari segi bahasa, kata pendidik dalam bahasa Arab dijumpai kata ustadz, mudarris, mua'llim dan mu'addib. Kata ustadz jamaknya asaatidz yang berarti teacher (guru), professor (gelar akademik), jenjang dibidang intelektual, pelatih, penulis dan penyair.). Adapun kata mudarris berarti teacher (guru), instsructor (pelatih) dan lecture (dosen) Selanjutnya kata mu'allim yang juga berarti teacher (guru), instructor (pelatih), trainer (pemandu). Selanjutnya kata mu'addib berarti educator (pendidik) atau teacher in Koranic school (guru dalam lembaga pendidikan al Qur'an).

Menurut denim (2011) bahwa kata pendidik secara fungsional menunjukkan kepada seseorang yang melakukan kegiatan dalam memberikan pengetahuan, ketrampilan, pendidikan, pengalaman dan sebagainya. Orang yang melakukan kegiatan ini bisa siapa saja dan di mana saja. Di rumah orang yang melakukan tugas tersebut ialah kedua orang tua karena secara moral dan teologis merekalah yang diserahi tanggung jawab pandidikan anaknya. Selanjutnya di 
sekolah tugas tersebut dilakukan oleh guru dan di masyarakat dilakukan oleh organisasi-organisasi kependidikan dan sebagainya. Atas dasar ini, Abuddin Nata menyebutkan bahwa yang termasuk ke dalam pendidik itu bisa kedua orang tua, guru, tokoh masyarakat dan sebagainya .

\section{B. Pengertian Tenaga Kependidikan}

Tenaga Kependidikan adalah anggota masyarakat yang mengabdikan diri dan diangkat untuk menunjang penyelenggaraan pendidikan. Yang termasuk ke dalam tenaga kependidikan adalah: kepala satuan pendidikan; pendidik; dan tenaga kependidikan lainnya. Kepala Satuan Pendidikan yaitu orang yang diberi wewenang dan tanggung jawab untuk memimpin satuan pendidikan tersebut. Kepala Satuan Pendidikan harus mampu melaksanakan peran dan tugasnya sebagai edukator, manajer, administrator, supervisor, leader, inovator, motivator, figur dan mediator (Emaslim-FM) Istilah lain untuk Kepala Satuan Pendidikan adalah: Kepala Sekolah, Rektor, Direktur, serta istilah lainnya.

Menurut Usman (2006) standar kompetensi pendidik dan tenaga kependidikan meliputi empat komponen yaitu: 1) kompetensi pedagogi (andragogi), 2) kompetensi kepribadian, 3) kompetensi social dan 4) kompetensi professional. Untuk lebih jelasnya masing-masing kompetensi dijabarkan sebagai berikut:

\section{Kompetensi Pedagogik (Andragogi)}

Kompetensi pedagogik (andragogi) merupakan kemampuan yang berkenaan dengan pemahaman terhadap peserta didik/warga belajar dan pengelola pembelajaran yang mendidik dan dialogis. Secara substantif kompetensi ini mencakup kemampuan pemahaman terhadap peserta didik, perancangan dan pelaksanaan pembelajaran, memahami kurikulum, evaluasi hasil belajar, dan pengembangan peserta didik untuk mengaktualisasikan berbagai potensi yang dimilikinya.

\section{Kompetensi Kepribadian}

Kompetensi kepribadian merupakan kemampuan personal yang mencerminkan kepribadian yang mantap, stabil, dewasa, arif, dan berwibawa, menjadi teladan bagi peserta didik/warga belajar, dan berakhlak mulia.

3. Kompetensi Sosial

Kompetensi sosial berkenaan dengan kemampuan pendidik sebagai bagian dari masyarakat untuk berkomunikasi dan bergaul secara efektif dengan peserta didik/warga belajar, sesama pendidik, tenaga kependidikan, orangtua/wali peserta didik/warga belajar, dan masyarakat sekitar.

4. Kompetensi Profesional

Kompetensi profesional merupakan kemampuan yang berkenaan dengan penguasaan materi pembelajaran secara luas dan mendalam yang mencakup penguasaan substansi isi materi kurikulum matapelajaran dan substansi keilmuan yang menaungi materi kurikulum tersebut, serta menambah wawasan keilmuan sebagai PTK.

\section{Standar Kualifikasi Pendidik}

Kualifikasi akademik guru melalui pendidikan formal: 1. Kualifikasi Akademik Guru PAUD/TK/RA
Guru pada PAUD/TK/RA harus memiliki kualifikasi akademik pendidikan minimum diploma empat (D-IV) atau sarjana (S1) dalam bidang pendidikan anak usia dini atau psikologi yang diperoleh dari program studi yang terakreditasi.

2. Kualifikasi Akademik Guru SD/MI

Guru pada SD/MI, atau bentuk lain yang sederajat, harus memiliki kualifikasi akademik pendidikan minimum diploma empat (D-IV) atau sarjana (S1) dalam bidang pendidikan SD/MI (D-IV/S1 PGSD/PGMI) atau psikologi yang diperoleh dari program studi yang terakreditasi.

3. Kualifikasi Akademik Guru SMP/MTs

Guru pada SMP/MTs, atau bentuk lain yang sederajat, harus memiliki kualifikasi akademik pendidikan minimum diploma empat (D-IV) atau sarjana (S1) program studi yang sesuai dengan mata pelajaran yang diajarkan/diampu, dan diperoleh dari program studi yang terakreditasi.

4. Kualifikasi Akademik Guru SMA/MA

Guru pada SMA/MA, atau bentuk lain yang sederajat, harus memiliki kualifikasi akademik pendidikan minimum diploma empat (D-IV) atau sarjana (S1) program studi yang sesuai dengan mata pelajaran yang diajarkan/diampu, dan diperoleh dari program studi yang terakreditasi.

5. Kualifikasi Akademik Guru SDLB/SMPLB/SMALB Guru pada SDLB/SMPLB/SMALB, atau bentuk lain yang sederajat, harus memiliki kualifikasi akademik pendidikan minimum diploma empat (D-IV) atau sarjana (S1) program pendidikan khusus atau sarjana yang sesuai dengan mata pelajaran yang diajarkan/diampu, dan diperoleh dari program studi yang terakreditasi.

6. Kualifikasi Akademik Guru SMK/MAK

Guru pada SMK/MAK atau bentuk lain yang sederajat, harus memiliki kualifikasi akademik pendidikan minimum diploma empat (D-IV) atau sarjana (S1) program studi yang sesuai dengan mata pelajaran yang diajarkan/diampu, dan diperoleh dari program studi yang terakreditasi.

\section{Tenaga Kependidikan}

Orang yang berpartisipasi dalam penyelenggaraan pendidikan di satuan pendidikan, walaupun secara tidak langsung terlibat dalam proses pendidikan, di antaranya:

1. Wakil-wakil/Kepala Urusan, umumnya pendidik yang mempunyai tugas tambahan dalam bidang yang khusus, untuk membantu Kepala Satuan Pendidikan dalam penyelenggaraan pendidikan pada institusi tersebut. Contoh: Kepala Urusan Kurikulum.

2. Tata Usaha, adalah Tenaga Kependidikan yang bertugas dalam bidang administrasi instansi tersebut. Bidang administrasi yang dikelola di antaranya; Administrasi surat menyurat dan pengarsipan, Administrasi Kepegawaian, Administrasi Peserta Didik, Administrasi Keuangan, Administrasi Inventaris dan lain-lain. Ad berarti intensif, sedangkan ministrare berarti melayani, membantu, dan memenuhi atau menyediakan (Husaini Usman, 2006).

3. Laboran, adalah petugas khusus yang bertanggung jawab terhadap alat dan bahan di Laboratorium. Laboran adalah petugas non guru yang membantu guru untuk melaksanakan 
kegiatan praktikum/peragaan (meliputi penyiapan bahan, membantu pelaksanaan praktikum serta mengemasi/ membersihkan bahan dan alat setelah praktikum). Selain itu, Laboran adalah teknisi yang membantu guru dalam melaksanakan KBM yang berupa peragaan atau praktikum.

4. Pustakawan, ialah seseorang yang bekerja di perpustakaan dan membantu orang menemukan buku, majalah, dan informasi lain. Pada tahun 2000-an, pustakawan juga mulai membantu orang menemukan informasi menggunakan komputer, basis data elektronik, dan peralatan pencarian di internet. Terdapat berbagai jenis pustakawan, antara lain pustakawan anak, remaja, dewasa, sejarah, hukum, dsb. Pustakawan wanita disebut sebagai pustakawati.

5. Bimbingan Konseling (BK) Fungsi bimbingan dan konseling secara umum adalah sebagai fasilitator dan motivator client dalm upaya mengatasi dan mencegah problema kehidupan client dengan kemampuan yang ada pada diri sendiri.Sesuai dengan uraian sebelumnya bahwa bimbingan dan konseling bertujuan agar peserta didik dapat menemukan dirinya, mengenal dirinya dan mampu merencanakan masa depannya.

6. Petugas keamanan (penjaga sekolah), Petugas kebersihan, dan lainnya.

Dari beberapa paparan di atas dapat disimpulkan bahwa tenaga kependidikan bertugas melaksanakan administrasi, pengelolaan, pengembangan, pengawasan, dan pelayanan teknis untuk menunjang proses pendidikan pada satuan pendidikan. Tenaga kependidikan mencakup pimpinan satuan pendidikan, penilik satuan pendidikan nonformal, pengawas satuan pendidikan formal, tenaga perpustakaan, tenaga laboratorium, teknisi sumber belajar, tenaga lapangan pendidikan, tenaga administrasi, psokolog, pekerja sosial, terapis, tenaga kebersihan sekolah, dan sebutan lain untuk petugas sejenis yang bekerja pada satuan pendidikan.

\section{E. Peran dan Fungsi Tenaga Pendidik}

Terdapat Peran dan Fungsi Tenaga Pendidik sebagai berikut: 1.Mampu menemukan pembawaan (bakat) peserta didiknya. 2.Mampu menolong peserta didiknya dalam perkembangannya.

3.Mampu menunjukkan jalan yang terbaik bagi perkembangan peserta didiknya

4. Mampu mengadakan evaluasi setiap waktu sebagai bentuk perhatian terhadap perkembangan peserta didiknya.
5. Mampu memberikan bimbingan dan penyuluhan terhadap peserta didik yang menghadapi kesulitan dalam proses pendidikannya.

6. Mampu memahami bakat bawaan para peserta didiknya danberusaha memberi jalan agar mereka mampu mengembangkan potensi dirinya melalui pendidikan itu sendiri.

7. Mampu dan pandai berinstropeksi diri.

8.Pendidik harus pandai memilih metode atau teknik pengajaran yang sesuai dengan materi pembelajaran dan peserta didiknya serta lingkungan sekitarnya. (Hamzah B. Uno, 2008).

\section{KESIMPULAN}

Pendidik adalah individu yang mampu melakukan tindakan pendidikan dalam satu situasi pendidikan untuk mencapai tujuan pendidikan. Staf pengajar seperti guru, dosen, konselor, tutor, widyaiswara, tutor, instruktur, dan fasilitator. Setiap pendidik memiliki posisi masing-masing, memiliki peran sesuai dengan posisi dan fungsinya. Masing-masing saling melengkapi, tidak ada yang menempati posisi dominan dalam berkontribusi pada upaya mencapai tujuan pendidikan. Peran atau tugas guru adalah sebagai pendidik, guru, pembimbing, direktur, pembimbing, penilai dan evaluator siswa. Peran tersebut dilakukan untuk mencapai tujuan pendidikan. Sebagai pendidik, mereka harus memiliki strategi atau cara agar siswa mereka berhasil dalam pendidikan.

\section{Daftar Pustaka}

Afriansyah, H. (2019). Administrasi Peserta Didik. Padang. https://doi.org/10.17605/OSF.IO/NRXH8

Danim, Sudarman, Profesi Kependidikan, (Bandung : CV. Alfabeta, 2011)

Husaini, Usman. 2006. Manajemen Pendidikan. Bandung : PT Raja Grafindo Persada.

Uno, Hamzah B. 2009. Teori motivasi dan Pengukurannya (Analisis di Bidang Pendidikan).Jakarta : Bumi Aksara. 